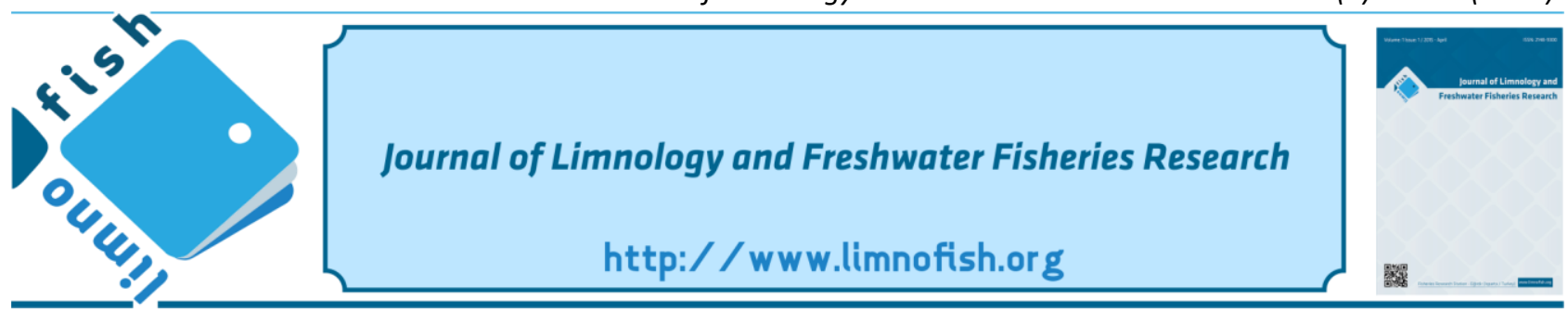

\title{
Age and Growth of Garra rufa (Heckel, 1843) from Merzimen Stream, Euphrates River Basin, Turkey
}

\author{
Erdoğan ÇIÇEK ${ }^{*}$ (iD), Burak SEÇER ${ }^{1}$ (i), Selda ÖZTÜRK ${ }^{\text {(D) }}$, Sevil SUNGUR² (iD) \\ ${ }^{1}$ Department of Biology, Faculty of Art and Sciences, Nevşehir Hacı Bektaş Veli University, 50300, Nevşehir, Turkey \\ ${ }^{2}$ Health Services Vocational School, Nevşehir Hacı Bektaş Veli University, 50300, Nevşehir, Turkey
}

\section{A B STRACT}

This study was carried out to determine the population parameters of Garra rufa in Merzimen Stream, Euphrates River Basin between May and November 2013. A total of 365 specimens were caught by electro shocker. The age of the sampled specimens ranged from 0 to $\mathrm{V}$ age groups. Total length and weight varied from 2.9 to $16.8 \mathrm{~cm}$ with a mean of $9.67 \pm 3.52 \mathrm{~cm}$ and 0.21 to $69.27 \mathrm{~g}$ with a mean of $15.69 \pm 14.75 \mathrm{~g}$, respectively. The length-weight relationship was obtained as $\mathrm{W}=0.0124 \mathrm{~L}^{2.9888}$ and the $\mathrm{b}$ value indicated the isometric growth. Estimated population parameters were calculated as $\mathrm{L}_{\infty}: 19.98 \mathrm{~cm}, \mathrm{k}: 0.275, \mathrm{t}_{0}:-1.157$. Fulton's condition factor and growth performance index were estimated as $\mathrm{K}: 1.24$ and $\Phi^{\prime}: 2.04$. Total (Z), natural (M), and fishing (F) mortalities and the exploitation rate $(\mathrm{E})$ were estimated $0.452,0.295,0.156$, and 0.347 , respectively.

Keywords: Mortality, exploitation rate, Gaziantep, population parameters

\section{ARTICLE INFO}

\section{RESEARCH ARTICLE}

Received : 27.03 .2020

Revised : : 10.07.2020

Accepted : :14.09.2020

Published : 29.04.2021

DOI:10.17216/LimnoFish.710127

\section{* CORRESPONDING AUTHOR}

erdogancicek@nevsehir.edu.tr

Phone : +90 5303449938

\section{Merzimen Çayı (Fırat Havzası) Garra rufa (Heckel, 1843) Popülasyonuna Ait Yaş ve Büyüme Parametreleri \\ Öz: Bu çalışma Merzimen Çayı Garra rufa popülasyonuna ait populasyon dinamiği parametrelerini belirlenmesi amacıyla Mayıs- Kasım 2013 tarihleri arasında yürütülmüştür. Elektroşok kullanılarak toplam 365 örnek yakalanmıştır. Yakalanan bireylerin yaşları 0 ile V. yaş grupları arasındadır. İncelenen bireylerin boy değerlerinin 2,9-16,8 cm ve ağırlık değerlerinin ise 0,21-69,27 g arasında değişim gösterdiği belirlenmiş olup ortalama total boy ve ağırlık değerleri sırasıyla $9,67 \pm 3,52 \mathrm{~cm}$ ve $15,69 \pm 14,75 \mathrm{~g}$ olarak hesaplanmıştır. Boy-ağırlık ilişkisi $\mathrm{W}=0,0124 \mathrm{~L}^{2,9888}$ olarak belirlenmiş olup izometrik büyüme özelliği sergilediği görülmüştür. Diğer populasyon değişkenleri ise $\mathrm{L}_{\infty}: 19,98 \mathrm{~cm}, \mathrm{k}: 0,275$ ve to: $-1,157$ olarak hesaplanmıştır. Fulton'un kondisyon faktörü ve büyüme performans endeksi K: 1,24 ve $\Phi^{\prime}: 2,04$ olarak tahmin edilmiştir. Toplam (Z), doğal (M) ve balıkçılık (F) nedeniyle olan ölüm oranları ve stoktan yararlanma düzeyi (E) sırasıyla $0,452,0,295,0,156$ ve 0,347 olarak hesaplanmıştır.}

Anahtar kelimeler: Ölüm oranı, sömürülme oranı, Gaziantep, populasyon parametreleri

How to Cite

Çiçek E, Seçer B, Öztürk S, Sungur S. 2021. Age and Growth of Garra rufa (Heckel, 1843) from Merzimen Stream, Euphrates River Basin, Turkey. LimnoFish. 7(1): 77-82. doi: 10.17216/LimnoFish.710127

\section{Introduction}

Garra rufa is a benthopelagic, non-migratory freshwater fish live in a variety of habitats including rivers, small muddy streams, small ponds, and lakes (Krupp and Schneider 1989). Its native distribution includes the Jordan, Orontes (=Asi), Quwayq, and Tigris-Euphrates river basins and coastal drainages of the eastern Mediterranean as well as much of southern Iran (Coad 2015). This species is relatively small (typically less than $15 \mathrm{~cm}$ ) and short-lived with the cooperation of other cyprinid species (Jarvis 2011). Garra rufa is a bottom dweller resident to a variety of freshwater habitats such as rivers, small muddy streams, small ponds, and lakes but it appears most often in lotic environments and hiding under and among stones and vegetation (Krupp and Schneider 1989). Briefly, G. rufa has been recorded in a wide range of water temperatures $\left(5.8-35.0^{\circ} \mathrm{C}\right)$ and appears capable of tolerating degraded systems (Jarvis 2011).

The species is known to adhere by suction to rocks with its ventral crescent-shaped mouth to feed on benthic algae (Özer et al. 1987; Yalçın-Özdilek and Ekmekçi 2006). It is a generalist feeder but periphyton tends to make up most of its diet as a benthic grazer. Garra rufa is not considering an 
economic value as a food source however it is an appropriate prey for piscivorous fishes. Eutrophication resulting from the input of various contaminants may result in favorable algae growth, important as a food source for G. rufa (YalçınÖzdilek and Ekmekçi 2006). Additionally, in the aquariums, juveniles' specimens acting as cleaner fish on ectoparasites of other aquarium species (Baensch and Riehl 2004). This species also occurs in Kangal hot springs in Central Anatolia, where it feeds on the skin scales of bathers, reducing illnesses such as neurodermatitis (Özçelik et al. 2000; Grassberger and Hoch 2006). This feeding behavior has piqued the interest of the spa industry in North America, where the fish is being imported to be utilized in a novel form of pedicure and manicure service (Jarvis 2011).

To estimate weight corresponding to a given length, growth rates, length and age structures, and other components of fish population dynamics, length, and weight data are needed (Froese 2006). Also, the length-weight data of a species in different habitats will be useful to compare the life history and morphological aspects of populations inhabiting different habitats (Segherloo et al. 2015). Therefore, investigations on the biological characteristics of fish are very important for fisheries management and the protection of wildlife of species.

Compared with other economically important species, little attention has been paid to the biology of small size species that have no commercial value (Abdoli et al. 2002). While there are some studies carried out on distribution, hematology, genetic, and morphology (Ergene and Çavaş 2004; Kara and Alp 2005; Karahan 2007; Kuru et al. 2010; Duman 2010; Durna et al. 2010; Yedier et al. 2016) up to now only one study found on the population features of G. rufa (Kirankaya et al. 2008) Valuable studies also conducted on the species to provide some information on the morphology, reproductive characteristics, life history aspects, length-weight relationships (Esmaeili et al. 2005; Yazdanpanahi 2005; Esmaeili and Ebrahimi 2006; Patimar et al. 2010; Teimori et al. 2011; Hamidan and Britton 2013) in Iran. There are very limited data available on age structure, growth, mortality rates of this species in Turkey or any country until now. Because of a few studies conducted on the population features of the species, little is known about the population parameters of the species. The aim of this study provides some information on age, growth, mortality, and exploitation rates of the G. rufa living in Merzimen Stream.

\section{Materials and Methods}

This sampling was carried out from May to November 2013 by monthly intervals in Merzimen Stream (Gaziantep), Euphrates River Basin. A total of 365 specimens were caught using a backpack electrofisher (SAMUS 725MP). The collected specimens were fixed in $10 \%$ formalin, and then transferred to the laboratory, and stored in $70 \%$ ethanol for further processing. In the laboratory, to determine the population parameters, the total length and weight of each sample were determined to be the nearest $1 \mathrm{~mm}$ and $0.01 \mathrm{~g}$, respectively. Remove the scale samples from the left side of the abdomen to the dorsal fin to determine the age. Immerse the fish scales in water and check them twice independently, without reference to previous readings, or to the length or weight of the fish under a stereo binocular microscope. The assessment of age is based on the determination of the number of rings on each scale.

Length-frequency data is plotted at $1 \mathrm{~cm}$ length intervals. The length-weight relationship (LWR) is determined according to the allometric equation $\mathrm{W}=\mathrm{a}^{*} \mathrm{~L}^{\mathrm{b}}$ (Sparre and Venema 1998). In this equation, $\mathrm{W}$ is the total weight, $\mathrm{L}$ is the total length, and $\mathrm{a}$ and $\mathrm{b}$ are regression constants. The increase in length and weight is represented by von Bertalanffy equation $\mathrm{L}_{\mathrm{t}}=\mathrm{L}_{\infty}\left[1-\mathrm{e}^{-\mathrm{k}(\mathrm{t}-\mathrm{t})}\right]$ and $\mathrm{W}_{\mathrm{t}}=\mathrm{W}_{\infty}\left[1-\mathrm{e}^{-\mathrm{k}(\mathrm{t}-\mathrm{t})} 0\right]^{\mathrm{b}}$. The growth parameters $\mathrm{L}_{\infty}, \mathrm{k}$ and $\mathrm{t}_{\mathrm{o}}$ and are estimated using the least square method recommended by Sparere and Venema (1998).

The least-squares method used to estimate the LLR with the total length between different body lengths to fit a simple linear regression model, where $\mathrm{Y}=\mathrm{a}+\mathrm{bX}$, where $\mathrm{Y}$ : various body lengths, $\mathrm{X}$ : body length, a: ratio constant, $b$ : regression coefficient. The percentage of length growth rate is calculated by the formula GR $=\left(\left(\mathrm{L}_{t+1}-\mathrm{L}_{\mathrm{t}}\right) /\left(\mathrm{L}_{\mathrm{t}}\right)\right) * 100$. Where $\mathrm{L}_{\mathrm{t}}$ : fish length at age $t, \mathrm{~L}_{\mathrm{t}+1}$ : fish length at age $\mathrm{t}+1$.

The following formula used to calculate the growth performance index $\left(\Phi^{\prime \prime}\right): \Phi^{\prime \prime}=\log \mathrm{k}+2 \log \mathrm{L}_{\infty}$ (Pauly and Munro, 1984). The Fulton condition factor $(\mathrm{K})$ is calculated by the following formula: $\mathrm{K}=100 \mathrm{~W} / \mathrm{L}^{\wedge} 3$ where; W: total weight, L: total length (Sparre and Venema 1998).

The correspondence between the empirical data and the expected distribution was tested by Khi2 test. The $b$ value was tested by $t$ test to verify that it is significantly different from isometric growth (b: 3).

\section{Results}

A total of 365 specimens were caught during the sampling period. Age of G. rufa varied from 0 to V 
age groups and the most frequent age groups were 0 (29.6\%), II (29.3\%), and I (21.4\%), respectively (Table 1). The total length ranged from 2.9 to $16.8 \mathrm{~cm}$ with a mean of $9.67 \pm 3.52 \mathrm{~cm}$ and total weight varied from 0.21 to $69.27 \mathrm{~g}$ with a mean of $15.69 \pm 14.75 \mathrm{~g}$. It was evident that $G$. rufa grew rapidly in its first year after which the growth rate decreased with increasing age.

Table 1. Age, length, and weight-frequency distribution of Garra rufa from Merzimen Stream.

\begin{tabular}{c|c|c|c|c|c|c|c}
\hline \multirow{2}{*}{ Age } & \multirow{2}{*}{$\mathbf{n}$} & \multirow{2}{*}{$\mathbf{n}$} & \multicolumn{3}{|c|}{ Total Length $(\mathbf{c m})$} & \multicolumn{2}{c}{ Total Weight (g) } \\
\cline { 4 - 8 } & & Range & Mean \pm SD & Growth Rate $(\boldsymbol{\%})$ & Range & Mean \pm SD \\
\hline 0 & 108 & 29.6 & $2.9-7.4$ & $5.31 \pm 1.06$ & & $0.21-7.58$ & $2.08 \pm 1.28$ \\
I & 78 & 21.4 & $6.7-12.1$ & $8.86 \pm 1.33$ & 66.85 & $3.5-24.80$ & $9.15 \pm 4.57$ \\
II & 107 & 29.3 & $9.3-13.7$ & $11.57 \pm 1.12$ & 30.58 & $8.51-40.43$ & $20.00 \pm 7.45$ \\
III & 54 & 14.8 & $11.1-15.5$ & $13.45 \pm 1.23$ & 16.24 & $16.40-53.60$ & $30.58 \pm 11.05$ \\
IV & 10 & 2.7 & $13.6-15.9$ & $15.04 \pm 0.84$ & 11.82 & $19.12-55.92$ & $38.61 \pm 12.16$ \\
V & 8 & 2.2 & $15.3-16.8$ & $16.29 \pm 0.48$ & 8.31 & $24.55-69.27$ & $62.34 \pm 6.32$ \\
\hline$\Sigma$ & 365 & & $2.9-16.8$ & $9.67 \pm 3.52$ & & $0.21-69.27$ & $15.69 \pm 14.75$ \\
\hline
\end{tabular}

The LLRs with total length among different body lengths were obtained as $\mathrm{FL}=(0.9374 * \mathrm{TL})-1.9924$, $\mathrm{SL}=(0.866 * \mathrm{TL})-3.1849$ and $\mathrm{SL}=(0.9252 * \mathrm{FL})-$ 0.2015 . Relationship equations among different body length parameters were found highly significant $(\mathrm{p}<0.01)$. The LWRs for G. rufa is presented in Figure 1. The relationship was determined as $\mathrm{W}=0.0124 * \mathrm{~L}^{2.9888}$ (95\% CI of b: 2.9386-3.0409). The $\mathrm{b}$ value was not significantly different from 3.0 $(\mathrm{p}<0.001)$, which indicates isometric growth of G. rufa in the Merzimen Stream.

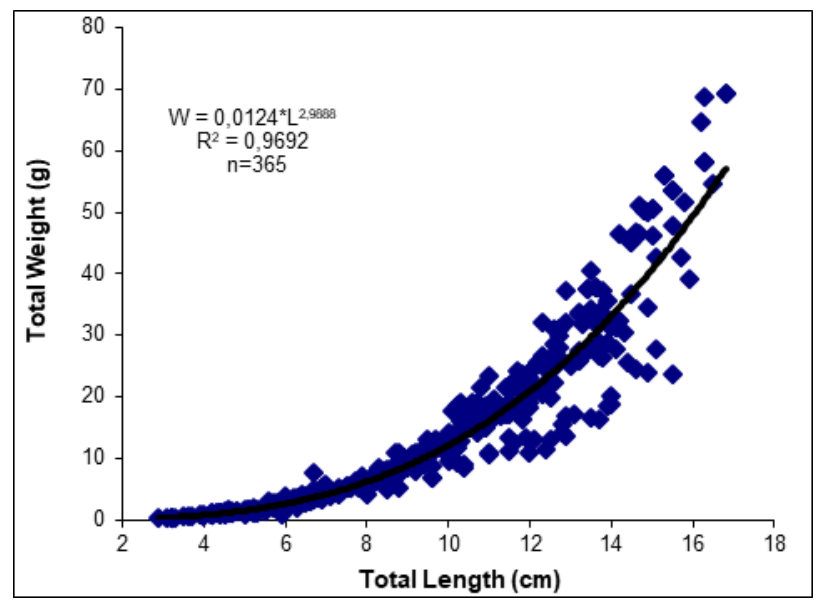

Figure 1. Length-weight relationship of Garra rufa from Merzimen Stream.

The von Bertalanffy growth parameters were estimated as follows $\mathrm{L}_{\infty}: 19.98 \mathrm{~cm}, \mathrm{~W}_{\infty}: 96.07 \mathrm{~g}$, $\mathrm{k}: 0.275$ year $^{-1}$, and $\mathrm{t}_{0}:-1.157$ years. The von Bertalanffy growth parameters calculated using the mean total length and total weight at ages were; $\mathrm{Lt}=$ $19.98\left[1-\mathrm{e}^{-0.275(\mathrm{t}+1.157)}\right], \mathrm{W}=96.07\left[1-\mathrm{e}^{-0.275(\mathrm{t}+1.157)}\right]^{2.9888}$. The growth performance index $\left(\Phi^{\prime}\right)$ and Fulton's Condition Factor $(\mathrm{K})$ were estimated as 2.04 and $1.24 \pm 0.25$ (0.47-2.52), respectively.

Instantaneous total $(\mathrm{Z})$, natural $(\mathrm{M})$, and fishing (F) mortalities were estimated $0.452,0.295$, and 0.156 year $^{-1}$, respectively. The exploitation rate (E) was calculated as 0.347 .

\section{Discussion}

The oldest fish in this study was $\mathrm{V}$ years old and the age was not determined older IV age in the previous studies (Kirankaya et al. 2008; Abedi et al. 2011; Pazira et al. 2013). The instantaneous growth rate also increased up to age I and then decreased with increasing age.

The maximum length was given as $14.1 \mathrm{~cm}$ in total length by Froese and Pauly (2019). However, a specimen is $16.8 \mathrm{~cm}$ in length was caught in this study. Therefore, it suggested that the maximum length of the species may reach moreover the observed length. Theoretical maximal length and weight were estimated at $19.98 \mathrm{~cm}$ and $96.07 \mathrm{~g}$, respectively in this study. The value of $L_{\infty}$ was $16.82 \mathrm{~cm}$ in the Dalaki and Shapour rivers population in Iran (Pazira et al. 2013). The value estimated in this study seems to be realistic.

The LLRs are useful for standardization of length type. The LLRs with total length among different body lengths were obtained as $\mathrm{FL}=(0.9374 * \mathrm{TL})$ 1.9924, $\mathrm{SL}=(0.866 * \mathrm{TL})-3.1849$ and $\mathrm{SL}=$ (0.9252*FL)-0.2015. Relationship equations among different body length parameters were found highly significant $(p<0.01)$. Gerami et al. (2013) reported the LLRs as SL $=0.728 \mathrm{TL}-1.030$ in Cholvar River, Iran. The LLRs has highly correlated with Gerami et al. (2013). For the variations of LLRs in the same species from different locations, the ecological conditions of the habits or variation in the physiology of animals, or both, are responsible (Le Cren 1951).

The calculated coefficient $b$ varied among the species from a minimum of 2.74 to a maximum of 3.196 with the median value of 3.02 in the previous studies (Table 2). According to these values, the growth characteristic of the species is generally isometric; however, it was also reported as negative allometric growth in some habitats (Table 2). According to the $\mathrm{b}$ value estimated in this study the growth type of G. rufa is isometric ( $\mathrm{b}=2.9888$, CI of 
b: 2.9386-3.0409) and show similarity with the median value of the previous studies given in Table 2.

Changes in the $b$ exponents of the same species may be due to differences in sampling, sample size, or length range. Also, differences in age, maturity, growth in food and environmental conditions (such as temperature and seasonality) also affect the $b$ value of the same species (Weatherley and Gill 1987). In addition, it is known that there are differences in biological characteristics between populations of the same species living in different regions (Pazira et al. 2013). Growth is affected by many factors, including gender, life history strategy, food type and availability, and temperature (Sarihan et al. 2007).

Table 2. Length-weight relationship and von Bertalanffy growth parameters for Garra rufa

\begin{tabular}{|c|c|c|c|c|c|c|c|}
\hline $\mathbf{a}$ & $\mathbf{b}$ & $\begin{array}{c}\mathbf{L}_{\infty} \\
(\mathbf{c m})\end{array}$ & $\begin{array}{c}\text { k } \\
\left(\text { year }^{-1}\right)\end{array}$ & $\begin{array}{c}\mathbf{t}_{0} \\
(\text { year})\end{array}$ & $\mathbf{K}$ & Habitat & References \\
\hline 0.0119 & 3.139 & & & & & Iran & $\begin{array}{c}\text { Esmaeili and Ebrahimi } \\
2006\end{array}$ \\
\hline 0.0063 & 3.112 & & & & $\begin{array}{c}2.03 \\
(0.87-3.14)\end{array}$ & Armand Stream, Iran & Abedi et al. 2011 \\
\hline 0.0075 & 3.149 & & & & & Euphrates River, Turkey & $\begin{array}{c}\text { Birecikligil and Ciçek } \\
2011\end{array}$ \\
\hline 0.0223 & 2.91 & 16.82 & 0.198 & -1.14 & & $\begin{array}{l}\text { Dalaki and Shapour } \\
\text { rivers, Iran }\end{array}$ & Pazira et al. 2013 \\
\hline 0.000005 & 3.196 & & & & $1.218 \pm 0.18$ & Cholvar River, Iran & Gerami et al. 2013 \\
\hline 0.00005 & 2.74 & & & & & Tange River, Iran & \multirow{13}{*}{ Segherloo et al. 2015} \\
\hline 0.00002 & 2.86 & & & & & Beshar River, Iran & \\
\hline 0.00001 & 2.99 & & & & & Mazoo River, Iran & \\
\hline 0.05 & 2.95 & & & & & Palangan River, Iran & \\
\hline 0.01 & 3.00 & & & & & Sirvan River, Iran & \\
\hline 0.00002 & 2.96 & & & & & Kheirabad, Iran & \\
\hline 0.00001 & 3.19 & & & & & Gamasiab River, Iran & \\
\hline 0.00001 & 3.16 & & & & & Ghalate River, Iran & \\
\hline 0.00001 & 3.08 & & & & & $\begin{array}{l}\text { Cheshme gerdab River, } \\
\text { Iran }\end{array}$ & \\
\hline 0.00001 & 3.14 & & & & & Maroon , Iran River & \\
\hline 0.00001 & 3.02 & & & & & Dashte chenir River, Iran & \\
\hline 0.00001 & 2.82 & & & & & Kheirak-shekarak, Iran & \\
\hline 0.00001 & 2.86 & & & & & Tange faryab River, Iran & \\
\hline 0.0044 & 3.06 & & & & & Jarrahi River, Iran & $\begin{array}{l}\text { Keivany and Zamani- } \\
\text { Faradonbe } 2017\end{array}$ \\
\hline 0.0124 & 2.9888 & 19.98 & 0.275 & -1.157 & $1.24 \pm 0.25$ & $\begin{array}{c}\text { Merzimen Stream, } \\
\text { Turkey }\end{array}$ & This study \\
\hline
\end{tabular}

Estimated Fulton's Condition Factor is highly correlated with Cholvar River population (Gerami et al. 2013), however, the value was found lower than that of the Armand Stream population (Abedi et al. 2011).

The growth performance index $\left(\Phi^{\prime}\right)$ was estimated as 2.04 in this study. This value has been estimated 1.71 and 1.79 for females and males, respectively by Pazira et al. (2013).

According to Froese (2006) and Clark (1928) had pointed out that condition factors can only be compared directly if either $b$ is not significantly different from 3 or the specimens to be compared are of similar length. The growth type is isometric because of $b$ value is not different from 3 . The estimated $\mathrm{K}$ value is highly correlated with Cholvar River (Gerami et al. 2013) however smaller than Armand Stream populations Abedi et al. (2011). The condition factor of a fish reflects physical and biological circumstances and fluctuations by interaction among feeding conditions, parasitic infections, and physiological factors (Le Cren 1951) ecosystems. According to Khristenko and Kotovska (2017) and Pravdin (1966) condition factors of the population may depend on not only its age and gender composition but also environmental elements and season as well. 
Mortality estimates are important for fisheries management. Knowing these ratios can help managers set the harvest limit to maximum sustainable yield (MSY) or optimal sustainable yield (OSY) so that resource stakeholders get the most benefit (Sparre et al. 1999). However, there was not found any study on the mortality rates of G. rufa. The mortality rates were estimated for the first time for this species in this study. According to mortality and exploitation rates, there was no overfishing pressure on the population.

\section{References}

Abdoli A, Rahmani H, Rasooli P. 2002. On the occurrence, diet and reproduction of Neogobius fluviatilis in Madarsoo Stream, Golestan National Park. Zool Middle East. 26: 123-128. doi:10.1080/09397140.2002.10637927

Abedi M, Shiva AH, Mohammadi H, Malekpour R. 2011. Reproductive biology and age determination of Garra rufa Heckel, 1843 (Actinopterygii: Cyprinidae) in central Iran. Turk J Zool. 35:317-323. doi:10.3906/zoo-0810-11

Baensch HA, Riehl R. 2004. Baensch Aquarium Atlas. Volume 3. Melle: Mergus, Verlag für Natur- und Heimtierkunde. Germany. p 1104.

Birecikligil S, Çiçek E. 2011. Length-weight relationships for 16 freshwater fishes caught in tributaries of Euphrates and Orontes rivers in Gaziantep (southeastern Anatolia), Turkey. J Appl Ichthyol. 27:1131-1132. doi:10.1111/j.1439-0426.2011.01760.x

Clark FN. 1928. The weight-length relationship of the California sardine (Sardina caerulea) at San Pedro. Division of Fish and Game. Fish Bull. No 12. 59 p.

Coad BW. 2015. Freshwater Fishes of Iran. [cited 2020 March 19] Available from http://www.briancoad.com/Species\%20Accounts/Co ntents\%20new.htm

Duman S. 2010. Cyprinion macrostomus Heckel, 1843 and Garra rufa Heckel, 1843 species of fishes that is living in Kangal (Sivas) Balıklı Çermik thermal hot spring with Topardiç Stream (Sivas) defines some heamatological parameters and non-specific immune respond. [PhD Thesis]. Çukurova University. 78 p.

Durna S, Bardakc1 F, Değerli N. 2010. Genetic diversity of Garra rufa Heckel, 1843 (Teleostei: Cyprinidae) in Anatolia. Biochem Syst Ecol. 38:83-92. doi:10.1016/j.bse.2009.12.009

Ergene S, Çavaş TA. 2004. Karyological Analysis of Garra rufa (Heckel, 1843) (Pisces, Cyprinidae) from the Eastern Mediterranean River Basin in Turkey. Turk J Vet Anim Sci. 28:497-500. doi:10.1080/11250003.2011.600338

Esmaeili HR, Ebrahimi M. 2006. Length-weight relationships of some freshwater fishes of Iran. J Appl Ichthyol. 22:328-329. doi:10.1111/j.1439-0426.2006.00653.x
Esmaeili HR, Yazdanpanahi M, Monsefi M. 2005. Reproductive biology of doctor fish, Garra rufa (Cyprinidae: Garrinae), in southwest of Iran. J Fish Biol. 67:282-282.

Froese R. 2006. Cube law, condition factor and weightlength relationships: history, meta-analysis and recommendations. J Appl Ichthyol. 22(4):241-253. doi:10.1111/j.1439-0426.2006.00805.x

Froese R, Pauly D. (Editors) 2019. FishBase. World Wide Web electronic publication. [cited 2020 March 16]. Available from www.fishbase.org, version 12/2019.

Gerami MH, Abdollahi D, Patimar R. 2013. Lengthweight, length-length relationship and condition factor of Garra rufa in Cholvar River of Iran. World Journal of Fish and Marine Sciences. 5(4): 358-361. doi:10.5829/idosi.wjfms.2013.05.04.7371

Grassberger M, Hoch W. 2006. Ichthyotherapy as alternative treatment for patients with psoriasis: A pilot study. Evid-based Compl Alt. 3(4): 483-488. doi:10.1093/ecam/nel033

Hamidan N, Britton JR. 2013. Length-weight relationships for three fish species (Capoeta damascina, Garra rufa and Nemacheilus insignis) native to the Mujib Basin, Jordan. J Appl Ichthyol. 29(2):480-481. doi:10.1111/jai.12120

Jarvis PL. 2011. Biological synopsis of Garra rufa. Canadian Manuscript Report of Fisheries and Aquatic Sciences 2946. [cited 2020 March 16]. Available from https://wavesvagues.dfompo.gc.ca/Library/343473.p df

Kara C, Alp A. 2005. Garra rufa Heckel, 1843'nın Ceyhan nehir sisteminde dağılımı ve bazı biyolojik özellikleri . Turkish Journal of Aquatic Life. 3(4):25-33.[in Turkish]

Karahan A. 2007. Investigation of cytogenetic and morfometric characteristics of Garra rufa and $G$. variabilis. [PhD Thesis]. Mersin University. $110 \mathrm{p}$.

Keivany Y, Zamani-Faradonbe M. 2017. Length-weight and length-length relationships for eight fish species from the Jarrahi River, southwestern Iran. J Appl Ichthyol. 33(4):864-866. doi:10.1111/jai.13396

Khristenko DS, Kotovska GO. 2017. Length-weight relationship and condition factors of freshwater bream Abramis brama (Linnaeus, 1758) from the Kremenchug Reservoir, Middle Dnieper. Turk J Fish Aquat Sci. 17:71-80. doi:10.4194/1303-2712-v17-1-09

Kırankaya ŞG, Ekmekçi FG, Özsoy GE. 2008. Comparition of the growth features of Gara rufa in Balıklı Hot Spring and Çermik Stream (Sivas, Kangal). Paper presented at: 19. National Biology Congress; 23-27 June 2008, Trabzon, Turkey.

Krupp F, Schneider W. 1989. The fishes of the Jordan River drainage basin and Azraq Oasis. Fauna of Saudi Arabia. 10:347-416.

Kuru N, Çinar K, Şenol N, Demirbağ E, Diler D. 2010. Endocrine cells in the gastrointestinal tract of Garra 
rufa. Kafkas Üniversitesi Veteriner Fakültesi Dergisi. 16(Suppl-B):235-241. doi:10.9775/kvfd.2009.1561

Le Cren ED. 1951. The length-weight relationship and seasonal cycle in gonad weight and condition in the perch (Perca fluviatilis). J Anim Ecol. 20(2): 201-219. doi: $10.2307 / 1540$

Özçelik S, Polat HH, Akyol M, Yalçın AN, Özçelik D, Marufdhah M. 2000. Kangal hot spring with fish and psoriasis treatment. J Dermatol. 27(6):386-390. doi:10.1111/j.1346-8138.2000.tb02188.x

Özer Z, Akpınar MA, Akçay M, Erdem Ü, Güler R, Yanıkoğlu A, Ergenoğlu B, Dere Ş, Savaşçı Ş. 1987. Determination of some biological and chemical properties of Kangal Balıklı Hot Spring (Sivas). Cumhuriyet University Journal of Basic Science. 5:1-34.

Patimar R, Ghasemi Chalanchi M, Chamanara V, Naderi L. 2010. Some life history aspects of Garra rufa (Heckel, 1843) in the Kangir River, Western Iran. Zool Middle East. 51:57-66. doi:10.1080/09397140.2010.10638441

Pauly D, Munro JL. 1984. Once more on the comparison of growth in fish and invertebrates. Fishbyte. 2(1):21.

Pazira AR, Moghdani S, Ghanbari F. 2013. Age structure and growth of the Gurra rufa (Cyprinidae), in southern Iran. Int J Biosci. 3(12):115-119. doi:10.12692/ijb/3.12.115-119

Pravdin IF. 1966. Rukovodstvo po izuchenijuryb (preimushhestvenno presnovodnyh). [Study guide of fishes (mainly freshwater)] Pishchevaya promishlenost. Moscaw, Russia. 376 p. [In Russian].

Sarıhan E, Çiçek E, Toklu B. 2007. Introduction to fish biology. Adana: Nobel Press. 137 p.
Segherloo IH, Tabatabaei SN, Mansouri A, Abdoli A, Ghalenoei M, Golzarianpour K. 2015. Length-weight relationships of Garra rufa, in the Tigris and Persian Gulf basins of Iran. International Journal of Aquatic Biology. 3(1):25-27. doi: 10.22034/ijab.v3i1.43

Sparre P, Ursin E, Venema S.C. 1999. Introduction to tropical fish stock assessment. Part 2. Exercises. FAO Fisheries Technical Paper. No. 306/2, Rev. 2. Rome. 94 p.

Sparre P, Venema SC. 1998. Introduction to tropical fish stock assessment. Part 1. Manual. FAO Fisheries Technical Paper. No. 306.1, Rev.2. Rome. 407 p.

Teimori A, Esmaeili HR, Ansari TH. 2011. Microstructure consideration of the adhesive organ in doctor fish, Garra rufa (Teleostei; Cyprinidae) from the Persian Gulf Basin. Turk J Fish Aquat Sci. 11:407-411. doi:10.4194/1303-2712-v11_3_10

Von Bertalanffy L. 1938. A quantitative theory of organic growth (inquiries on growth laws II). Hum Biol. 10(2):181-213. doi: $10.2307 / 41447359$

Weatherley H, Gill HS. 1987. The Biology of fish growth. London, England: Academic Press. 443 p.

Yalçın-Özdilek S, Ekmekçi FG. 2006. Preliminary data on the diet of Garra rufa (Cyprinidae) in the Asi basin (Orontes), Turkey. Cybium. 30(2):177-186.

Yazdanpanahi M. 2005. Reproductive biology of Garra rufa in a spring stream system, Zanjiran, Fars Province. [Master's Thesis]. Shiraz University. Iran. $158 \mathrm{p}$.

Yedier S, Kontaş S, Bostancı D, Polat N. 2016. Otolith and scale morphologies of doctor fish (Garra rufa) inhabiting Kangal Balıklı Çermik thermal spring (Sivas, Turkey). Iran J Fish Sci. 15(4):1593-1608. 